\title{
Photosynthetic characteristics and mycosporine-like amino acids under UV radiation: a competitive advantage of Mastocarpus stellatus over Chondrus crispus at the Helgoland shoreline?
}

Received: 15 November 1999 / Received in revised form: 28 February 2000 / Accepted: 10 March 2000

\begin{abstract}
Chondrus crispus and Mastocarpus stellatus both inhabit the intertidal and upper sublittoral zone of Helgoland, but with $C$. crispus generally taking a lower position. Measurements of chlorophyll fluorescence, activity of ribulose-1,5-bisphosphate carboxylase/oxygenase (RubisCO), and content and composition of UV absorbing mycosporine-like amino acids (MAAs) were conducted in the laboratory, to test whether susceptibility to UV radiation may play a role in the vertical distribution of these two species. Effective and maximal quantum yield of photochemistry as well as maximal electron transport rate $\left(\mathrm{ETR}_{\max }\right)$ in C. crispus were more strongly affected by UV-B radiation than in $M$. stellatus. In both species, no negative effects of the respective radiation conditions were found on total activity of RubisCO. Total MAA content in M. stellatus was up to 6-fold higher than in C. crispus and the composition of MAAs in the two species was different. The results indicate that, among others, UV-B sensitivity may be a factor restricting $C$. crispus to the lower intertidal and upper sublittoral zone, whereas $M$. stellatus is better adapted to UV radiation and is therefore more competitive in the upper intertidal zone.
\end{abstract}

Key words Chondrus crispus . Chlorophyll fluorescence . Mastocarpus stellatus $\cdot$ Mycosporine-like amino acids . $\mathrm{UV}$ radiation

\section{Introduction}

Both Chondrus crispus and Mastocarpus stellatus are abundant species of red algae along the coasts of the North Atlantic and inhabit the intertidal and upper sublit-

Communicated by K. Lüning

K. Bischof $(-) \cdot G$. Kräbs · D. Hanelt · C. Wiencke

Alfred Wegener Institute for Polar and Marine Research,

27515 Bremerhaven, Germany

e-mail: kbischof@awi-bremerhaven.de

Tel.: +49-471-4831417, Fax: +49-471-4831425 toral zone of rocky shorelines (Lüning 1990). However, M. stellatus was not recorded from the island of Helgoland before 1983 when a few sporophytes were introduced during a scientific campaign (Kornmann and Sahling 1994). In the following years, M. stellatus established and dispersed all over the island on hard substrates in the lower intertidal zone. C. crispus has always been regarded as an abundant species on Helgoland within its main distribution in the upper sublittoral and below the understorey of the intertidal zone (Kornmann and Sahling 1977). After the introduction of M. stellatus, competition between the two species may have been initiated at locations where their habitats overlap, leading to the presently observed zonation pattern. Previous comparative studies on temperature, desiccation and freezing resistance revealed a generally higher stress tolerance of $M$. stellatus (Mathieson and Burns 1971; Dudgeon et al. 1989, 1995), which may favour growth in variable environments, such as the intertidal and the upper sublittoral zone.

Recent studies stress the potential role of solar and especially UV radiation in determining macroalgal zonation patterns from polar to temperate regions (Dring et al. 1996a; Hanelt et al. 1997; Bischof et al. 1998a). Moreover, Maegawa et al. (1993) regard solar UV radiation as one of the most important factors controlling the depth distribution of red algae on the shore. In the study presented here, it was tested whether UV radiation may be a factor contributing to the distribution of populations of M. stellatus and C. crispus on the shores of Helgoland. Therefore, different photosynthetic parameters, such as effective quantum yield, maximal quantum yield of dark acclimated samples, and maximal electron transport rate $\left(\mathrm{ETR}_{\max }\right)$ as studied by pulse amplitude modulated fluorescence (PAM) measurements, as well as activity of ribulose-1,5-bisphosphate carboxylase/oxygenase (RubisCO) were determined during exposure of experimental individuals to artificial UV radiation. Additionally, the content of UV screening mycosporine-like amino acids (MAAs) was measured to test whether the species have different capabilities for protection against UV radiation. 


\section{Materials and methods}

Young thalli of Mastocarpus stellatus (Stackh. in With.) Guiry and Chondrus crispus Stackh. were collected from the same shore level in the NE Harbour of Helgoland (German Bight, North Sea; 54o $11^{\prime} \mathrm{N}, 7^{\circ} 53^{\prime} \mathrm{E}$ ) on 2 June 1999 during low tide and transferred to the laboratory. There, specimens were cleaned of epiphytes, and thallus branches about $2 \mathrm{~cm}$ long were removed to be cultivated in nutrient-enriched seawater (Provasoli 1986) and dim light for 2 days.

Samples were then grown at $10^{\circ} \mathrm{C}$ in 0.51 glass dishes $18 \mathrm{~cm}$ in diameter and exposed to a 16:8 h light:dark cycle, supplemented with $6 \mathrm{~h}$ of UV in the middle of the light phase, from 1000 to 1600 hours. Cultures, each containing up to 80 thallus branches per species and treatment, were stirred regularly to guarantee equal light exposure. Every alternate day, the medium in the dishes was replaced. The experimental material was exposed to artificial UV radiation generated by three UVA-340 (Q-Panel, Cleveland, USA) fluorescent tubes at irradiances of $10 \mathrm{~W} \mathrm{~m}^{-2} \mathrm{UV}-\mathrm{A}$ $(320-400 \mathrm{~nm})$ and $1 \mathrm{~W} \mathrm{~m}^{-2}$ UV-B (280-320 nm). Photosynthetically-active radiation (PAR) produced by daylight fluorescent tubes was $25 \mu \mathrm{mol} \mathrm{m}{ }^{-2} \mathrm{~s}^{-1}$. Experimental irradiance of PAR was measured with a Licor Li-189 radiometer (Quantum, USA), for the UV range, a RM-21 (Dr. Gröbel, Germany) bandpass radiometer equipped with broadband 2 p UV-A (320-400 nm) and UV-B $(280-320 \mathrm{~nm})$ sensors was used. Glass dishes were covered with different filter foils to cut off different wavelength ranges selectively from the spectrum emitted by the fluorescent tubes: samples receiving PAR + UV-A + UV-B were covered with an Ultraphan URT 300 foil (Digefra, Germany). To cut off only the UV-B range, a Folex PR foil (Dr. Schleussner, Germany) was used; to exclude the whole UV range (UV-A + UV-B) from the treatment, samples were covered with an Ultraphan URUV foil (Digefra). A comparison of the spectral properties of the different filter foils used in the experiment is given by Pérez-Rodríguez et al. (1998). For all parameters tested, sampling or measuring was conducted on the 1st, 2nd and 5th day of the experiment, immediately before the start of UV exposure, after 2, 4, and $6 \mathrm{~h}$ of UV irradiation and after 2 and $4 \mathrm{~h}$ after UV exposure had ceased.

During exposure in the climate chamber, measurements of effective quantum yield $\left(\Delta \mathrm{F} / \mathrm{Fm}^{\prime} ;\right.$ cf. Schreiber et al. 1994) under the different radiation conditions were carried out with a Diving PAM (Walz, Germany). Saturating pulse length was adjusted to $0.6 \mathrm{~s}$ with an intensity of approx. $5000 \mu \mathrm{mol} \mathrm{m} \mathrm{m}^{-2} \mathrm{~s}^{-1}$. Variation of effective quantum yield was high due to the differences among the light fields so that 20-40 yield determinations were carried out at each measuring point, and mean values and standard deviations were calculated. Maximal quantum yield of photochemistry was determined by the ratio of variable to maximal chlorophyll fluorescence $(\mathrm{Fv} / \mathrm{Fm})$ with a PAM 2000 chlorophyll fluorometer (Walz), following the protocol described in detail by Hanelt (1998). Subsequently, photosynthesis versus irradiance curves were recorded with the fluorometer as described by Bischof et al. (1999). From this, ETR max $_{\operatorname{mal}}$ values were extracted by regression analysis. Measurements of $\mathrm{Fv} / \mathrm{Fm}$ and $\mathrm{ETR}_{\max }$ were conducted in triplicate from randomly collected samples.

For enzyme analysis, at each measuring point, subsamples of approx. $0.8 \mathrm{~g}$ fresh weight were frozen in liquid nitrogen and stored until assay. Total activity of RubisCO in crude extracts was tested with a coupled photometric test generally following the method described by Gerard and Driscoll (1996). Crude extracts were prepared by grinding frozen algal material to a fine powder and transferring it into ice cold extraction buffer $(0.1 \mathrm{M}$ Tris-Cl, $2 \mathrm{mM}$ EDTA, $10 \mathrm{mM} \mathrm{MgCl}, 20 \%$ glycerol, $1 \%$ Triton X-100, $50 \mathrm{mM}$ DTT, $100 \mathrm{mM} \mathrm{Na}$ ascorbate, and $10 \mathrm{mM} \mathrm{NaHCO}$, at $\mathrm{pH}$ 7.6). $0.5 \mathrm{~g}$ fresh weight of tissue was mixed with $1 \mathrm{ml}$ of extraction buffer. The assay mixture contained $50 \mathrm{mM}$ HEPES, $10 \mathrm{mM}$ $\mathrm{NaHCO}_{3}, 20 \mathrm{mM} \mathrm{MgCl}, 0.2 \mathrm{mM}$ NADH, $5 \mathrm{mM}$ ATP, $5 \mathrm{mM}$ phosphocreatine, 5 units of creatine phosphokinase and 5 units of glyceraldehyde-3-phosphate dehydrogenase/phosphoglycerate kinase. Sample loads contained $25 \mu \mathrm{l}$ of extract, the reaction was started by adding ribulose-1,5-bisphosphate with a final concen- tration of $2 \mathrm{mM}$ in the cuvette. The time course of NADH oxidation was recorded by the decrease in absorbance at $340 \mathrm{~nm}$. Activity was expressed as declining absorbance per mg protein and second (mAbs mg protein $\left.{ }^{-1} \mathrm{~s}^{-1}\right)$. Overall content of soluble proteins in crude extracts was determined using a commercial protein assay (Bio Rad, USA). Protein content was determined by measuring extinction at $595 \mathrm{~nm}$ and calculating the concentration of proteins according to a calibration curve prepared with bovine serum albu$\min$.

For analysis of content and composition of MAAs, samples of about $10 \mathrm{mg}$ dry weight were prepared for HPLC analysis generally following the protocol of Karsten et al. (1998a) modified as follows: the mobile phase within the HPLC column was $10 \%$ aqueous methanol $(\mathrm{v} / \mathrm{v})$ plus $0.1 \%$ acetic acid $(\mathrm{v} / \mathrm{v})$ in water; the flow

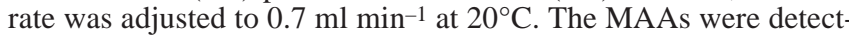
ed at $330 \mathrm{~nm}$ and absorption spectra (290-400 nm) were recorded at $1 \mathrm{~s}$ intervals directly on HPLC-separated peaks. Substances were identified according to spectra and retention time.

\section{Results}

Both species exhibited a differential response to the exposure to artificial UV radiation. In $C$. crispus, initial values of effective quantum yield $\left(\Delta \mathrm{F} / \mathrm{Fm}^{\prime}\right)$ were lower (0.455) than in M. stellatus $(0.543$; Fig. 1$)$. In both species, the changes in $\Delta \mathrm{F} / \mathrm{Fm}^{\prime}$ due to exposure to PAR or

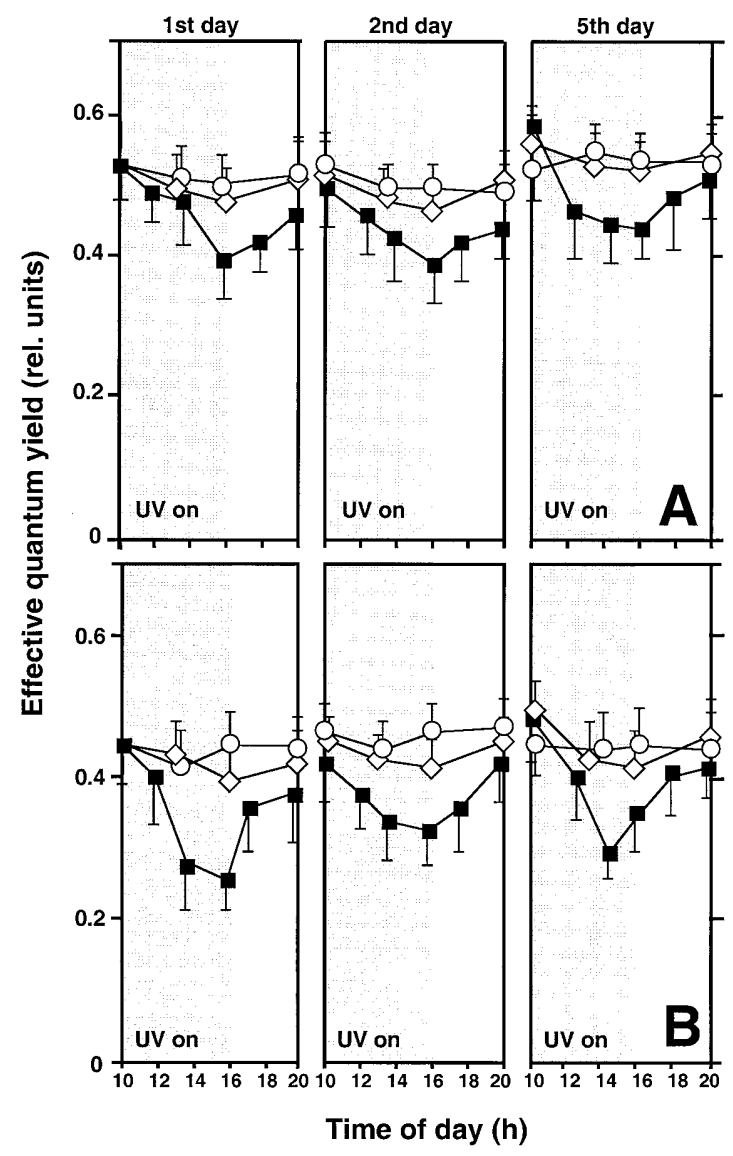

Fig. 1 Effective quantum yield of photosynthesis in Mastocarpus stellatus (A) and Chondrus crispus (B) during exposure (marked grey) to PAR $(\bigcirc)$, PAR + UV-A $(\diamond)$, and PAR + UV-A + UV-B (ם) and subsequent recovery in PAR only, for the 1st, 2nd and 5 th day of treatment; $n=20-40$, mean values \pm SD 


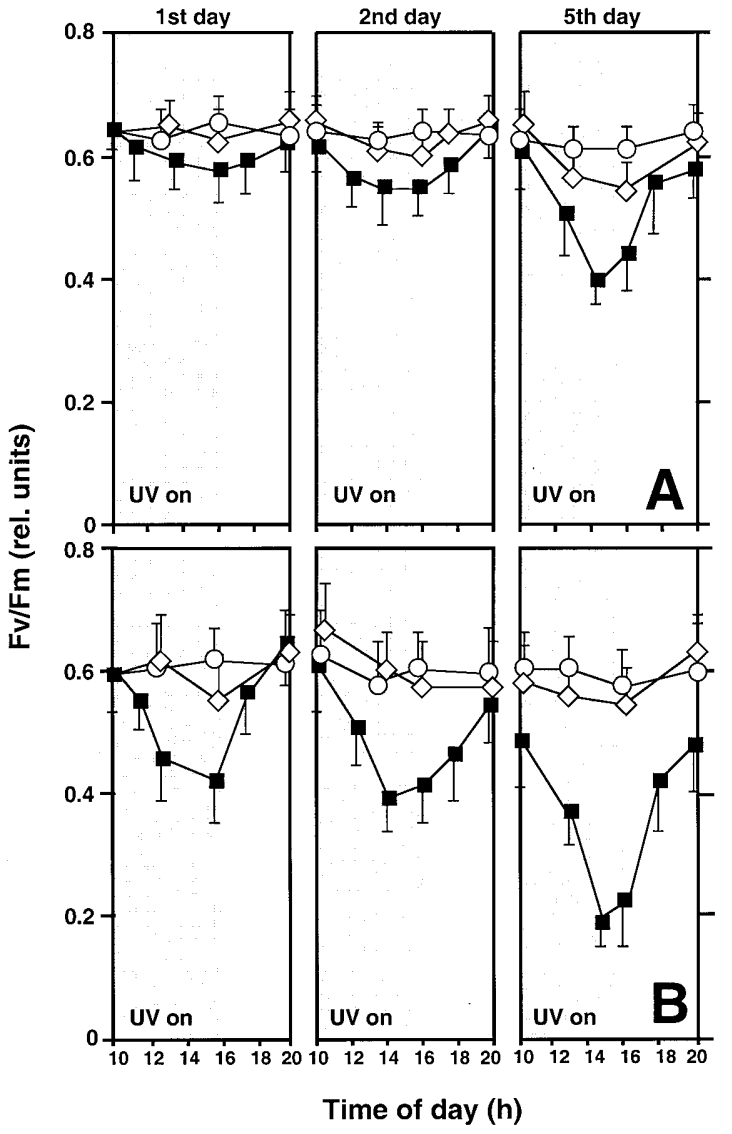

Fig. 2 Maximal quantum yield of photosynthesis $(\mathrm{Fv} / \mathrm{Fm})$ in Mastocarpus stellatus (A) and Chondrus crispus (B) during exposure (marked grey) to PAR $(\mathrm{O}), \mathrm{PAR}+\mathrm{UV}-\mathrm{A}(\diamond)$, and PAR + UV-A + UV-B (ם) and subsequent recovery in PAR only, for the 1 st, 2 nd and 5 th day of treatment; $n=3$, mean values \pm SD

PAR + UV-A were very small in the course of the experiment. In contrast, additional UV-B radiation resulted in a marked reduction of effective quantum yield (Fig. 1A, B): throughout the experiment, UV-B irradiated samples of $M$. stellatus exhibited a reduction of approx. $20 \%$ in $\Delta \mathrm{F} / \mathrm{Fm}^{\prime}$ after $6 \mathrm{~h}$ of exposure, while $C$. crispus showed a reduction to $60 \%$ of initial values on the first day. However, during the following days, there was a trend to a lesser degree of inhibition of $\Delta \mathrm{F} / \mathrm{Fm}^{\prime}$ in this species.

Exposure to UV-B radiation resulted in a strong reduction of maximal quantum yield $(\mathrm{Fv} / \mathrm{Fm})$ in $C$. crispus (Fig. 2B), while samples under PAR and PAR + UV-A radiation remained almost unaffected. The UV-B induced reduction in $\mathrm{Fv} / \mathrm{Fm}$ became more prominent in the course of the experiment: while during $6 \mathrm{~h}$ of exposure on the first day Fv/Fm dropped by $30 \%$ of initial values; a $70 \%$ decline was observed during exposure on the 5th day. Moreover, before the beginning of the fifth exposure, samples had not completely recovered overnight from the previous exposure. In contrast, in M. stellatus, maximal quantum yield was generally less affected by UV-B, with only a $15 \%$ reduction during exposure on the first day. However, also in this species, Fv/Fm values further declined in the course of the experiment, and were finally

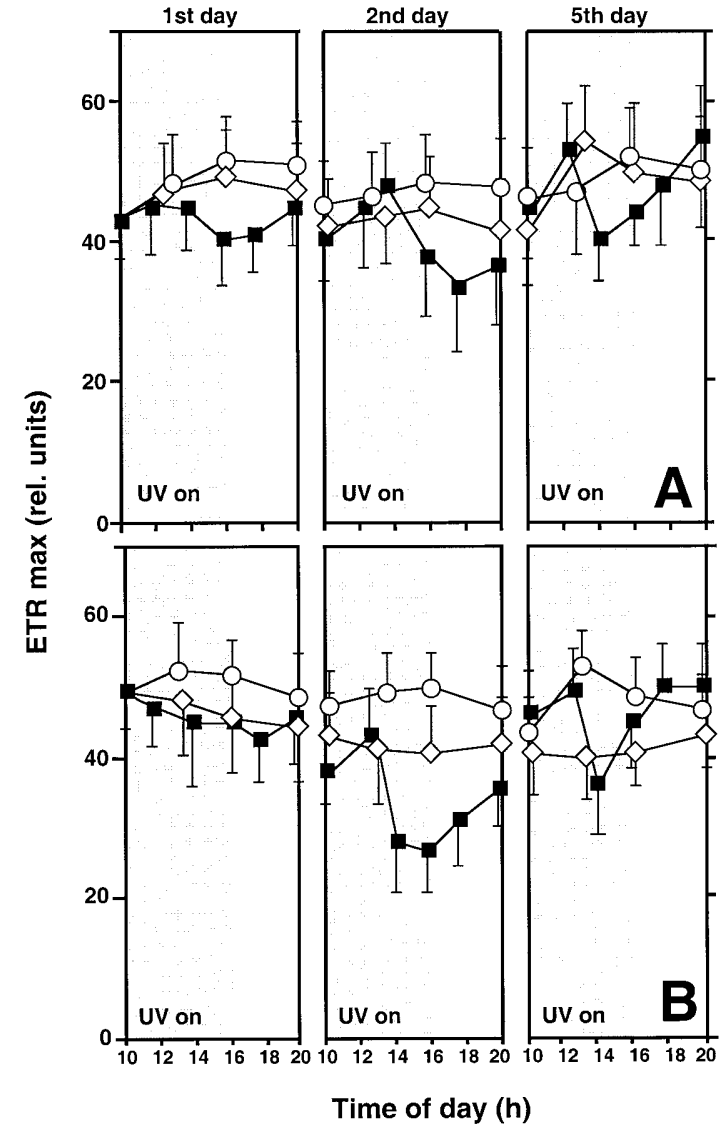

Fig. 3 Maximal electron transport rate $\left(E T R_{\max }\right)$ of photosynthesis in Mastocarpus stellatus (A) and Chondrus crispus (B) during exposure (marked grey) to PAR $(\mathrm{O}), \mathrm{PAR}+\mathrm{UV}-\mathrm{A}(\diamond)$, and PAR + UV-A + UV-B (ם) and subsequent recovery in PAR only, for the 1 st, 2 nd and 5 th day of treatment; $n=3$, mean values \pm SD

reduced to $60 \%$ of the initial values (Fig. 2A). Also in $M$. stellatus, no adverse effects on maximal quantum yield were observed in samples shielded from UV-B.

ETR $_{\max }$ values in samples of $M$. stellatus were moderately promoted throughout the experiment under the PAR and PAR + UV-A treatment, as compared to the initial values (Fig. 3A), while no significant changes were observed due to additional UV-B irradiation during the first day. In contrast, during the 2nd day, a reduction in ETR $_{\max }$ was observed in UV-B exposed samples; however, this was only obvious after $6 \mathrm{~h}$ of exposure and during the recovery phase after UV irradiation had already ceased. Samples of $C$. crispus exposed to PAR + UV-A showed a trend to slightly lower ETR max $_{\text {values in the }}$ course of the experiment, while values in PAR-irradiated samples remained unaffected (Fig. 3B). In contrast to the reactions of UV-B exposed samples on the first and 5th day of the experiment, $\mathrm{ETR}_{\max }$ dropped to $50 \%$ of initial values after $6 \mathrm{~h}$ of UV-B exposure on the 2 nd day.

Generally, under all experimental radiation conditions, RubisCO activities in samples of $M$. stellatus were higher than the initial values. Results obtained from UVB irradiated samples were inconsistent and erratic but, especially in these samples, enzyme activity seemed to 


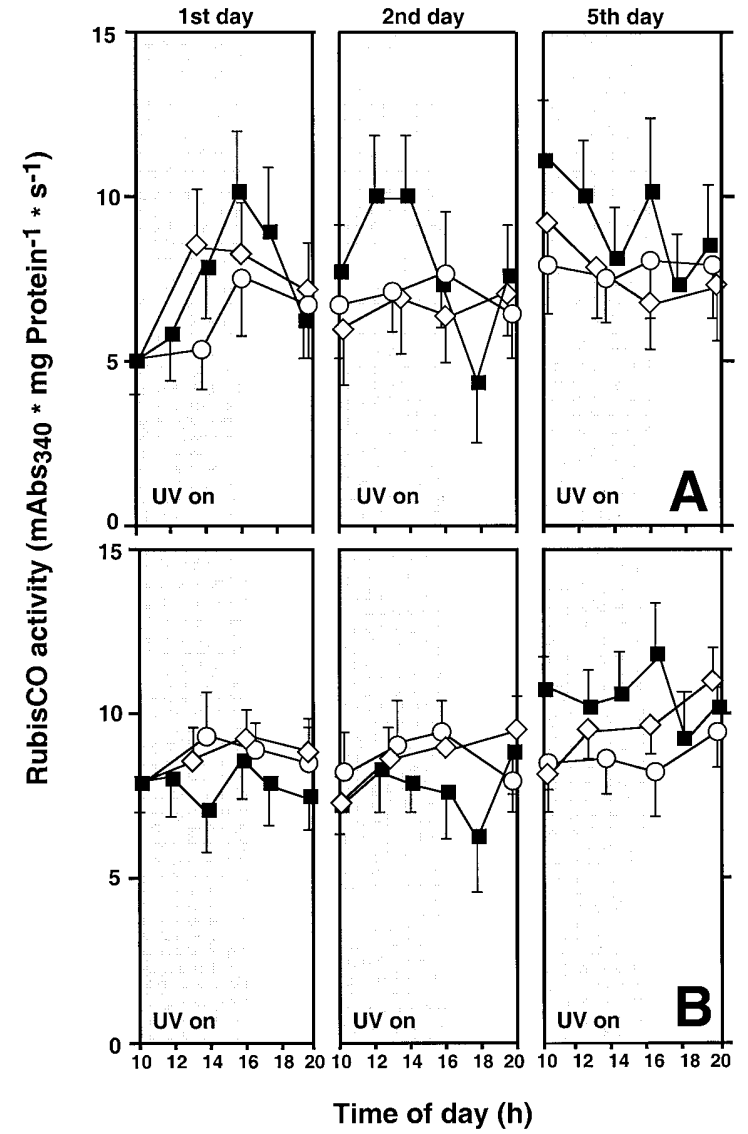

Fig. 4 Total activity of RubisCO in Mastocarpus stellatus (A) and Chondrus crispus (B) during exposure (marked grey) to PAR $(\bigcirc)$, PAR + UV-A $(\diamond)$, and PAR + UV-A + UV-B (ם) and subsequent recovery in PAR only, for the 1st, 2nd and 5th day of treatment; $n=3$, mean values $\pm \mathrm{SD}$

be promoted during exposure (Fig. 4A). In C. crispus, overall RubisCO activity was not significantly altered during the first 2 days of the experiment (Fig. 4B). However, throughout the fifth exposure, samples exposed to UV-B generally exhibited a 50\% increase in activity compared with the initial values.

There were major differences in the content and composition of MAAs between the two species (Table 1).
Throughout the treatment, overall content in M. stellatus was up to nearly 6-fold higher than in C. crispus. Shinorine was the only MAA detected in M. stellatus. During the experiment, its content increased strongly to almost the double its initial value. In contrast, there was no trace of this compound in initial samples of C. crispus. However, in the course of the experiment, the de novo synthesis of shinorine contributed strongly to the almost $50 \%$ increase in total MAA content. The contents of asterina and palythene doubled, while the concentration of palythine did not change significantly during the treatment.

\section{Discussion}

Our results show that photosynthesis in M. stellatus was less sensitive to the experimental UV-B irradiances than C. crispus. Previous comparisons of the physiological responses of these two species revealed a generally higher tolerance of $M$. stellatus to different kinds of abiotic stress (Dudgeon et al. 1989, 1995). The authors showed that the fronds of both species are very similar in terms of ecophysiological characteristics (e.g. high photosynthetic capacity), but differences in stress tolerance characteristics, such as lower net photosynthetic rates during desiccation and freezing and slower recovery in C. crispus, may be important factors in terms of competition and occupied niches. Freezing is suggested to be especially important in controlling the distribution of these species on the shore (Dudgeon et al. 1989). For Helgoland, this may be an important factor as freezing periods over several weeks are frequently observed during winter (A. Wagner, personal communication). Generally, the higher stress tolerance of $M$. stellatus results in this species prevailing on exposed locations in the lower intertidal zone. In contrast, lower light compensation points of $C$. crispus permit optimal light utilisation and high growth rates at greater water depth or below canopies (Dudgeon et al. 1995).

Differences between the species in effective quantum yields under UV-B exposure were small (Fig. 1), but maximal quantum yields exhibited a much higher UV-B tolerance in M. stellatus (Fig. 2) indicating that energy

Table 1 Composition and content of mycosporine-like amino acids (MAAs) in Chondrus crispus and Mastocarpus stellatus, in samples taken before the start of the experiment and after the end of the fifth exposure to UV-B, mean values $(n=3) \pm$ SD

\begin{tabular}{|c|c|c|c|c|c|}
\hline Compound & $\begin{array}{l}\text { Absorption maximum } \\
(\mathrm{nm})\end{array}$ & $\begin{array}{l}\text { C. crispus } \\
\text { Initial content }\end{array}$ & $\begin{array}{l}\left(\mathrm{mg}^{*} \mathrm{~g} \text { dry weight }\right. \\
\text { Final content }\end{array}$ & $\begin{array}{l}\text { M. stellatus } \\
\text { Initial content }\end{array}$ & $\begin{array}{l}\left(\mathrm{mg}^{*} \mathrm{~g} \text { dry weight }\right. \\
\text { Final content }\end{array}$ \\
\hline Shinorine & 334 & no trace & $\begin{array}{l}0.118 \\
( \pm 0.025)\end{array}$ & $\begin{array}{l}2.650 \\
( \pm 0.500)\end{array}$ & $\begin{array}{l}4.440 \\
( \pm 1.090)\end{array}$ \\
\hline Palythine & 320 & $\begin{array}{l}0.294 \\
( \pm 0.087)\end{array}$ & $\begin{array}{l}0.285 \\
( \pm 0.107)\end{array}$ & No trace & No trace \\
\hline Asterina & 330 & $\begin{array}{l}0.089 \\
( \pm 0.023)\end{array}$ & $\begin{array}{l}0.167 \\
( \pm 0.079)\end{array}$ & No trace & No trace \\
\hline$\Sigma$ MAAs & & $\begin{array}{l}0.430 \\
( \pm 0.113)\end{array}$ & $\begin{array}{l}0.670 \\
( \pm 0.221)\end{array}$ & $\begin{array}{l}2.650 \\
( \pm 0.500)\end{array}$ & $\begin{array}{l}4.440 \\
( \pm 1.090)\end{array}$ \\
\hline
\end{tabular}


transfer between light harvesting complex and reaction centre should be more efficient (Krause and Weis 1991). In both species, UV-B induced impairment of maximal quantum yield increased during the treatment. These findings suggest that adverse effects on photosynthetic antenna systems may become more and more prominent in the course of repeated UV exposures and result in chronic damage to the antennae (Demmig-Adams and Adams 1992; Hanelt 1996). Different findings were reported in a study on the brown alga Alaria esculenta (Bischof et al. 1999). In this species, inhibition of maximal quantum yield becomes smaller and recovery faster after a few repeated exposures to UV. However, the A. esculenta samples were kept in dim light for 2 days between each repeated exposure, allowing complete recovery and acclimation to UV radiation.

It is important to note that in both species studied, the impairment of maximal as well as effective quantum yield was exclusively due to UV-B radiation; this is in contrast to a similar study on UV effects on several other red algal species from Helgoland (Dring et al. 1996a), where the UV-A range also strongly contributed to the reduction of $\mathrm{Fv} / \mathrm{Fm}$ values. However, as experimental conditions were different between the studies, a comparison might be difficult. In the study cited, algae were exposed to UV-A and UV-B irradiances which were up to $50 \%$ higher than those in our study, but with the same low background of PAR. The strong effect of UV-A was predominantly found in red algae from the deep sublittoral zone, which are probably adapted to low irradiances. The samples used in our study were collected at the beginning of June and therefore might be acclimated to high irradiances which, in turn, might also reduce their sensitivity towards UV (Cen and Bornman 1990; Bischof et al. 1999). It was also shown by Dring et al. (1996a) that sensitivity towards UV exposure changes with the season. Due to the unnaturally enhanced UV-B:PAR ratio in laboratory experiments the detrimental effects of UV-B exposure might be overestimated compared to field conditions (Teramura 1986). Nevertheless, the higher sensitivity to UV-B radiation in $C$. crispus, as shown in our experiments, is likely to reflect higher susceptibility under natural radiation conditions, compared to $M$. stellatus; however, this remains to be confirmed in further studies.

The different composition and higher concentration of MAAs in M. stellatus might be one reason for its generally lower sensitivity of photosynthesis towards UV radiation compared to $C$. crispus [see also Karsten et al. (1998b), Dunlap and Shick (1998) and Sinha et al. (1998) for reviews on MAAs]. The potential of MAAs to protect the photosynthetic apparatus against UV radiation was shown by Karsten et al. (1999) in the Arctic endemic red alga Devaleraea ramentacea. A detailed study of the formation of MAAs in C. crispus was performed by Karsten et al. (1998a) who showed that shinorine is synthesised under UV radiation, while synthesis of palythine is mainly induced by PAR. This is in line with our results as PAR was low and concentration of palythine remained unchanged during the treatment. A high initial content of shinorine in M. stellatus may favour its occurrence in sun-exposed locations, while the capability of C. crispus to synthesise shinorine certainly shows the potential to acclimate to changes in light climate.

After the release of M. stellatus in 1983, it first established in the intertidal zone at locations with a hard substrate, a position which is not inhabited by C. crispus. Generally, the type of substrate plays a major role in the settlement of M. stellatus (I. Bartsch, personal communication). At our study site in the NE harbour, the typical habitats of $C$. crispus and M. stellatus apparently overlap, as both species seem to find favourable conditions for establishment and growth.

For a physiological comparison it was important to collect samples at the same time from the same shore level, as these factors may strongly influence the UV sensitivity of macroalgae (Dring et al. 1996a; Bischof et al. 1998b), and acclimation to changing radiation conditions can proceed rapidly (Bischof et al. 1999). For C. crispus, increasing UV sensitivity with increasing growth depth and its acclimation to the respective in situ light climate was described in detail by Sagert et al. (1997). In a study of MAA formation in the red alga, Devaleraea ramenta$c e a$, the strong correlation between MAA content and sampling depth was also shown (Karsten et al. 1999). Additionally, all plants used in the experiments were of similar size and morphology, which are also important factors in UV tolerance (Dring et al. 1996b). As all environmental conditions were identical until harvest, acclimation to different conditions can be excluded as a reason for the differential response towards experimental UV exposure. Thus, genetic adaptation in the investigated species might be responsible for the different UV sensitivity in our experiments. The lower sensitivity of $M$. stellatus to UV-B radiation, which was shown in our study, might, in turn, be one aspect enabling this species to occur in more sunexposed areas in the field. In summary, at sun-exposed locations, different composition of MAAs and a higher resistance of photosynthetic reactions may represent a competitive advantage of $M$. stellatus over C. crispus, which is restricted to more shaded habitats.

Acknowledgements The authors are most grateful to Andreas Wagner for technical assistance, and to Inka Bartsch for helpful comments on the manuscript. This work was financially supported by the European Commission (Project ENV4-CT96-0188, DG 12). Contribution No. 1768 of the Alfred Wegener Institute for Polar and Marine Research.

\section{References}

Bischof K, Hanelt D, Wiencke C (1998a) UV-radiation can affect depth-zonation of Antarctic macroalgae. Mar Biol 131: 597-605

Bischof K, Hanelt D, Tüg H, Karsten U, Brouwer P, Wiencke C (1998b) Acclimation of brown algal photosynthesis to UVradiation in Arctic coastal waters. Polar Biol 20:388-395

Bischof K, Hanelt D, Wiencke C (1999) Acclimation of maximal quantum yield of photosynthesis in the brown alga Alaria esculenta under high light and UV radiation. Plant Biol 1: 435-444 
Cen YP, Bornman JF (1990) The response of bean plants to UV-B radiation under different irradiances of background visible light. J Exp Bot 41:1489-1495

Demmig-Adams B, Adams WW III (1992) Photoprotection and other responses of plants to high light stress. Annu Rev Plant Physiol Plant Mol Biol 43:599-626

Dring MJ, Wagner A, Boeskov J, Lüning K (1996a) Sensitivity of intertidal and subtidal red algae to UVA and UVB radiation, as monitored by chlorophyll fluorescence measurements: influence of collection depth and season, and length of irradiation. Eur J Phycol 31:293-302

Dring MJ, Makarov V, Schoschina E, Lorenz M, Lüning K (1996b) Influence of ultraviolet-radiation on chlorophyll fluorescence and growth in different life history stages of three species of Laminaria (Phaeophyta). Mar Biol 126:183-191

Dudgeon SR, Davison IR, Vadas RL (1989) Effect of freezing on photosynthesis of intertidal macroalgae: relative tolerance of Chondrus crispus and Mastocarpus stellatus (Rhodophyta). Mar Biol 101:107-114

Dudgeon SR, Kübler JE, Vadas RL, Davison IR (1995) Physiological responses to environmental variation in intertidal red algae: does thallus morphology matter? Mar Ecol Prog Ser 117:193-206

Dunlap WC, Shick JM (1998) Ultraviolet radiation-absorbing mycosporine-like amino acids in coral reef organisms: a biochemical and environmental perspective. J Phycol 34:418-430

Gerard VA, Driscoll T (1996) A spectrophotometric assay for RubisCO activity: application to the kelp Laminaria saccharina and implications for radiometric assays. J Phycol 32:880-884

Hanelt D (1996) Photoinhibition of photosynthesis in marine macroalgae. Sci Mar 60:243-248

Hanelt D (1998) Capability of dynamic photoinhibition in Arctic macroalgae is related to their depth distribution. Mar Biol 131:361-369

Hanelt D, Melchersmann B, Wiencke C, Nultsch W (1997) Effects of high light stress on photosynthesis of polar macroalgae in relation to depth distribution. Mar Ecol Prog Ser 149:255-266

Karsten U, Franklin LA, Lüning K, Wiencke C (1998a) Natural ultraviolet radiation and photosynthetically active radiation induce formation of mycosporine-like amino acids in the marine macroalga Chondrus crispus (Rhodophyta). Planta 205:257-262

Karsten U, Sawall T, Hanelt D, Bischof K, Figueroa FL, FloresMoya A, Wiencke C (1998b) An inventory of UV-absorbing mycosporine-like amino acids in macroalgae from polar to warm-temperate regions. Bot Mar 41:443-453
Karsten U, Bischof K, Hanelt D, Tüg H, Wiencke C (1999) The effect of ultraviolet radiation on photosynthesis and ultravioletabsorbing substances in the endemic Arctic macroalga Devaleraea ramentacea (Rhodophyta). Physiol Plant 105:58-66

Kornmann P, Sahling PH (1977) Meeresalgen von Helgoland. Helgol Wiss Meeresunters 29:1-289

Kornmann P, Sahling PH (1994) Meeresalgen von Helgoland. Zweite Ergänzung. Helgol Meeresunters 48:365-406

Krause GH, Weis E (1991) Chlorophyll fluorescence and photosynthesis: the basics. Annu Rev Plant Physiol Plant Mol Biol 42:313-349

Lüning K (1990) Seaweeds. Wiley, New York

Maegawa M, Kunieda M, Kida W (1993) The influence of ultraviolet radiation on the photosynthetic activity of several red algae from different depths. Jpn J Phycol 41:207-214

Mathieson AC, Burns RL (1971) Ecological studies of economic red algae. I. Photosynthesis and respiration of Chondrus crispus Stackhouse and Gigartina stellata (Stackhouse) Batters. J Exp Mar Biol Ecol 7:197-206

Pérez-Rodríguez E, Gómez I, Karsten U, Figueroa FL (1998) Effects of UV radiation on photosynthesis and excretion of UV-absorbing compounds of Dasycladus vermicularis (Dasycladales, Chlorophyta) from southern Spain. Phycologia 37:379-387

Provasoli L (1986) Media and prospects for the cultivation of marine algae. In: Watanabe A, Hattori A (eds) Cultures and collections of algae. In: Proceedings of the Japanese Conference Hakone. Japanese Society of Plant Physiology, Tokyo, pp 63-75

Sagert S, Forster RM, Feuerpfeil P, Schubert H (1997) Daily course of photosynthesis and photoinhibition in Chondrus crispus (Rhodophyta) from different shore levels. Eur J Phycol 32:363-371

Schreiber U, Bilger W, Neubauer C (1994) Chlorophyll fluorescence as a nonintrusive indicator for rapid assessment of in vivo photosynthesis. Ecol Stud 100:49-70

Sinha RP, Klisch M, Gröninger A, Häder DP (1998) Ultravioletabsorbing/screening substances in cyanobacteria, phytoplankton and macroalgae. J Photochem Photobiol B: Biol 47:83-94

Teramura AH (1986) Interaction between UV-B radiation and other stresses in plants. In: Worrest RC, Caldwell MM (eds) Stratospheric ozone reduction, solar ultraviolet radiation and plant life. NATO ASI series G8, Springer, Berlin Heidelberg New York, pp 327-343 